\title{
KESEIMBANGAN HARGA DAN KUANTITAS PASAR SUSU SEGAR DI INDONESIA
}

\author{
${ }^{1}$ Lilis Imamah Ichdayati, ${ }^{2}$ Eny Dwiningsih, ${ }^{3}$ Risma Kurnia Putri \\ ${ }^{1,2,3}$ Agribusiness Department, Syarif Hidayatullah State Islamic University Jakarta, Indonesia \\ Email: ${ }^{1}$ lilis.imamah@uinjkt.ac.id, ${ }^{2}$ eny.dwiningsih@uinjkt.ac.id,
}

\begin{abstract}
Abstrak
Produksi susu dalam negeri hanya mampu memenuhi kebutuhan permintaan konsumsi susu sebesar $30 \%$ saja, sisanya $70 \%$ dipasok dari impor. Di sisi lain tingkat konsumsi susu perkapita Indonesia relatif rendah. Hal ini menjadi peluang bagi usaha ternak sapi perah dalam menyediakan susu sapi segar. Artikel ini bertujuan mengetahui faktor-faktor yang mempengaruhi biaya produksi susu segar, harga dan kuantitas susu segar sebagai keseimbangan permintaan dan penawaran dalam pasar susu segar. Sumber data sekunder dengan periode 1993-2017. Instrumen analisis menggunakan metode persamaan simultan two stage least square (@LSL).

Hasil analisis menunjukkan bahwa model persamaan biaya produksi susu segar dipengaruhi oleh variabel biaya pakan, listrik dan air, obat-obatan dan bahan bakar. Model persamaan produksi susu segar dipengaruhi oleh variabel jumlah sapi laktasi dan jumlah pakan konsentrat. Dari sisi pasar susu segar, model persamaan penawaran susu segar dipengaruhi oleh variabel jumlah susu segar dan harga teh sebagai komplementer, diikuti varibel harga susu segar dan harga kopi sebagai substitusi. Sedangkan dari model persamaan permintaan yang berpengaruh adalah variabel pendapatan perkapita, jumlah produksi, harga teh dan harga kopi sebagai produk komplementer dan substitusi. Model persamaan harga susu segar dipengaruhi oleh variabel total biaya produksi dan jumlah permintaan susu segar.
\end{abstract}

Kata Kunci : susu segar, permintaan, penawaran.

\begin{abstract}
Domestic milk production is only able to meet the demand for milk consumption by 30\%, the remaining $70 \%$ is supplied from imports. On the other hand, Indonesia's per capita milk consumption level is relatively low. This is an opportunity for dairy cattle businesses to provide fresh cow's milk. The purpose of this article is to know the factors that affect the cost of producing fresh milk, the price and quantity of fresh milk as a balance of demand and supply in the fresh milk market. Secondary data sources for the period 1993-2017. The analysis instrument uses the two stage least square (@LSL) simultaneous equation method.

The results of the analysis are an equation model of the cost of producing fresh milk influenced by costs of feed, electricity and water, drugs and fuel. The equality model of fresh milk production is influenced by the number of lactation cows and the amount of concentrate feed. From the fresh milk market side, the fresh milk supply equation model is influenced by the amount of fresh milk and the price of tea as complementary, followed by the price of fresh milk and the price of coffee as a substitute. While the influential demand equation model is the income per capita, the amount of production, the price of tea and the price of coffee as a complementary and substitute product. The fresh milk price equation model is influenced by the total production cost and the amount of fresh milk demand.
\end{abstract}

Keywords: fresh milk, demand, supply. 


\section{PENDAHULUAN}

Sektor petenakan sebagai sumber pemenuhan gizi masyarakat terutama zat protein, mampu menyumbang PDB tahun 2017 sebesar $15,33 \%$ dari total PDB sektor pertanian nasional. Dengan pertumbuhan pertahun cukup mengesankan sebesar positif 15,02 $15,33 \%$ (BPS, 2018). Hal ini menunjukkan sektor peternakan memiliki keunggulan dan memiliki nilai strategis dalam pemenuhan kebutuhan protein yang terus meningkat sejalan dengan pertumbuhan penduduk.

Salah satu produk peternakan adalah susu. Berdasarkan data Kementerian Pertanian (2018), tingkat konsumsi susu dalam negeri tahun 2016 baru mencapai 4.284 .000 ton atau setara dengan 11,8 liter/ kapita/tahun. Tingkat konsumsi ini tergolong rendah dibandingkan negara-negara Asia Tenggara, seperti Malaysia mencapai tiga kali lebih besar yakni 36,2 liter/kapita/tahun. Ako (2013) menyatakan bahwa profil konsumsi susu segar sangat sedikit hanya $18 \%$ selebihnya $82 \%$ susu yang dikonsumsi dalam bentuk susu putih bubuk.

Di sisi lain, ketersediaan susu dalam negeri baik dalam bentuk segar maupun olahan belum mencukupi permintaan konsumsi susu. Kondisi ini mendorong kegiatan impor susu dari negara penghasil susu. Hal ini terlihat dari data Kementerian Pertanian (2018) bahwa produksi susu sapi segar dalam negeri hanya mampu menyediakan $30 \%$ dari kebutuhan susu dalam negeri, sisanya dipasok melalui impor. Sehingga Indonesia berada pada posisi net onsumer dalam peta perdagangan dunia produk-produk susu.

Posisi seperti ini secara langsung merugikan peternak sapi perah lokal yang mengandalkan potensi sumberdaya alam. Upaya mendorong meningkatkan produksi susu dalam negeri melalui kebijakan program percepatan peningkatan produktivitas dan kualitas hasil ternak (Supianto, 2018). Tantangan pelaksanaan kebijakan ini menurut Siregar (2003) adalah rendahnya harga susu di tingkat peternak. Harga yang rendah menyebabkan peternak tidak termotivasi meningkatkan produktivitas susu segar, karena peningkatan produksi susu yang diupayakan peternak tidak berdampak pada peningkatan penghasilannya.

Dari sisi permintaan konsumen susu segar, selalu lebih besar dari kemampuan peternak sapi perah menyediakan susu segar secara nasional. Hal ini menunjukkan masih terbukanya peluang pasar bagi produksi susu segar. Namun fungsi pasar tidak hanya sebatas penyerapan produksi susu segar tetapi juga sekaligus sebagai penentu harga. Walaupun pasar masih terbuka luas, namun bila harga yang terbentuk tidak sesuai dengan harapan peternak, maka tidak terjadi peningkatan produksi yang signifikan.

Permasalahan tersebut mendorong perlunya analisis mengenai faktor-faktor yang mempengaruhi biaya produksi, penawaran, permintaan dan harga susu segar dalam negeri di Indonesia.

\section{KERANGKA TEORI / KONSEP}

Teori yang dikemukakan Sugiarto dkk (2002) bahwa permintaan dan penawaran suatu barang dengan sendirinya dapat mencapai keseimbangan harga dan jumlah barang yang diperjual-belikan. Dengan demikian dalam pasar seimbang, variabel harga akan menjadi penghubung antara variabel jumlah permintaan dan penawaran suatu barang. Sehingga harga dipengaruhi oleh perubahan jumlah permintaan dan selanjutnya dapat mempengaruhi penawaran.

Dari sisi penawaran, terdapat produsen hasilhasil pertanian seperti susu sapi perah. Menurut Widjajanto dalam Hasanah (2015) komponen biaya dalam usaha ternak sapi perah terdiri atas biaya tetap dan biaya variabel. Biaya tetap merupakan biaya yang harus dikeluarkan dengan jumlah yang tetap pada periode waktu tertentu tanpa melihat jumlah produksi yang dihasilkan. Sedangkan biaya variabel adalah biaya yang dikeluarkan dengan jumlah yang berubah sesuai dengan jumlah produksi yang dihasilkan. Selanjutnya, Hasanah (2015) dalam penelitiannya menggunakan variabel biaya tetap terdiri dari biaya penyusutan ternak, kandang dan peralatan. Sedangkan biaya variabel terdiri 
dari biaya yang dikeluarkan untuk pembelian barang dan jasa dalam usaha ternak sapi perah. Menurut BPS dalam Survei Ongkos Usaha Ternak (2017) komponen variabel dalam total biaya produksi ternak sapi perah diantaranya adalah variabel biaya pakan, biaya tenaga kerja, biaya listrik dan air, biaya obat-obatan dan biaya bahan bakar.

Kusnadi dan Juarini (2007) menyatakan bahwa untuk mengoptimalkan produksi susu dalam usaha ternak sapi perah dapat dilakukan salah satunya dengan memberikan suplementasi pakan konsentrat dan frekuensi pemberiannya. Siregar (2003) menyatakan bahwa peluang untuk meningkatkan produksi susu nasional juga terbuka dengan cara perbaikan pakan baik dari segi kuantitas dan kualitas. Supriadi, dkk (2017) menambahkan bahwa pemberian pakan konsentrat berbagai jenis kualitas terhadap sapi yang sedang dalam masa laktasi mampu meningkatkan jumlah produksi air susu sapi perah.

Produksi susu sapi perah yang dijual ke pasar susu segar, maka berlaku teori yang dikemukakan oleh Rahardja dan Manurung (2010) bahwa variabel penawaran diantaranya dipengaruhi oleh harga barang itu sendiri, harga barang lain, biaya input atau total biaya produksi dan jumlah produksi barang yang nantinya akan ditawarkan. Harga barang itu sendiri memiliki hubungan positif terhadap jumlah penawaran. Untuk memenuhi kaidah teori, maka barang lain yang dapat menjadi komplemen dan substitusi susu segar adalah harga teh dan harga kopi. Apabila harga suatu barang substitusi meningkat, maka penawaran suatu barang juga akan meningkat (bersifat searah). Sebaliknya apabila harga barang komplementer meningkat, maka penawaran suatu barang akan menurun (bersifat tidak searah). Menurut Syamsuddin dan Karya (2018), posisi komplemen dan substitusi suatu barang dapat diukur menggunakan elastisitas silang. Tanda negatif pada nilai elastisitas silang menunjukkan bahwa kedua komoditas memiliki hubungan komplementer, begitupun sebaliknya.
Dari sisi permintaan, teori Rahardja dan Manurung (2010) menyatakan bahwa permintaan akan suatu barang dipengaruhi oleh harga barang itu sendiri, harga barang lain dan pendapatan per kapita. Teori permintaan yang menyatakan bahwa harga suatu barang memiliki hubungan tidak searah terhadap jumlah permintaan. Namun berbeda dengan harga susu sapi segar, hasil penelitian Zuhriyah (2010) menunjukkan bahwa harga susu segar memiliki tanda positif terhadap jumlah permintaan susu. Hal ini terjadi karena industri berbahan baku susu segar masih belum terpenuhi oleh produksi susu segar domestik. Menurut Rahardja dan Manurung (2010) bahwa pendapatan perkapita merupakan cerminan dari daya beli masyarakat. Makin tinggi tingkat pendapatan masyarakat, maka daya beli masyarakat juga akan semakin meningkat.

Penetapan harga susu sapi segar sejalan dengan teori yang dijelaskan oleh Amir (2005) bahwa faktor biaya merupakan bagian penting dalam penetapan harga. Selain itu, ditinjau dari Permentan No. 25 Tahun 2017 tentang peredaran dan penyediaan susu, dinyatakan bahwa penentuan harga susu segar dalam negeri selain melihat dari segi kualitas susu yang dihasilkan oleh peternak, juga harus mempertimbangkan total biaya produksi dan keuntungan yang diperoleh oleh peternak.

\section{METODE PENELITIAN}

Penelitian ini menggunakan data sekunder berdasarkan deret waktu tahun 1993 - 2017. Lembaga penyedia data adalah BPS dengan berbagai tahun. Analisis data yang digunakan adalah metode deskriptif kuantitatif dengan persamaan simultan dengan metode Two Stages Least Squares (@ SLS). Alat bantu yang digunakan adalah program Statistical Analysis System (SAS) versi 9.1.

Jumlah variabel yang ditetapkan ada 18 unit terdiri dari 5 variabel endogen membentuk sistem pasar pada kondisi seimbang dan 13 variabel eksogen. Asumsi dalam model berada pada keseimbangan pasar dimana jumlah penawaran susu segar domestik akan sama dengan jumlah permintaannya, karena 
keterbatasan data jumlah permintaan susu. Dengan demikian jumlah permintaan susu segar diasumsikan sama dengan jumlah penawaran susu segar yang ditawarkan oleh produsen/peternak sapi perah. Sesuai hukum permintaan dan penawaran, maka variabel penghubung keduanya adalah harga susu segar.

Persamaan simultan penawaran dan permintaan susu sapi segar domestik digambarkan sebagai berikut:

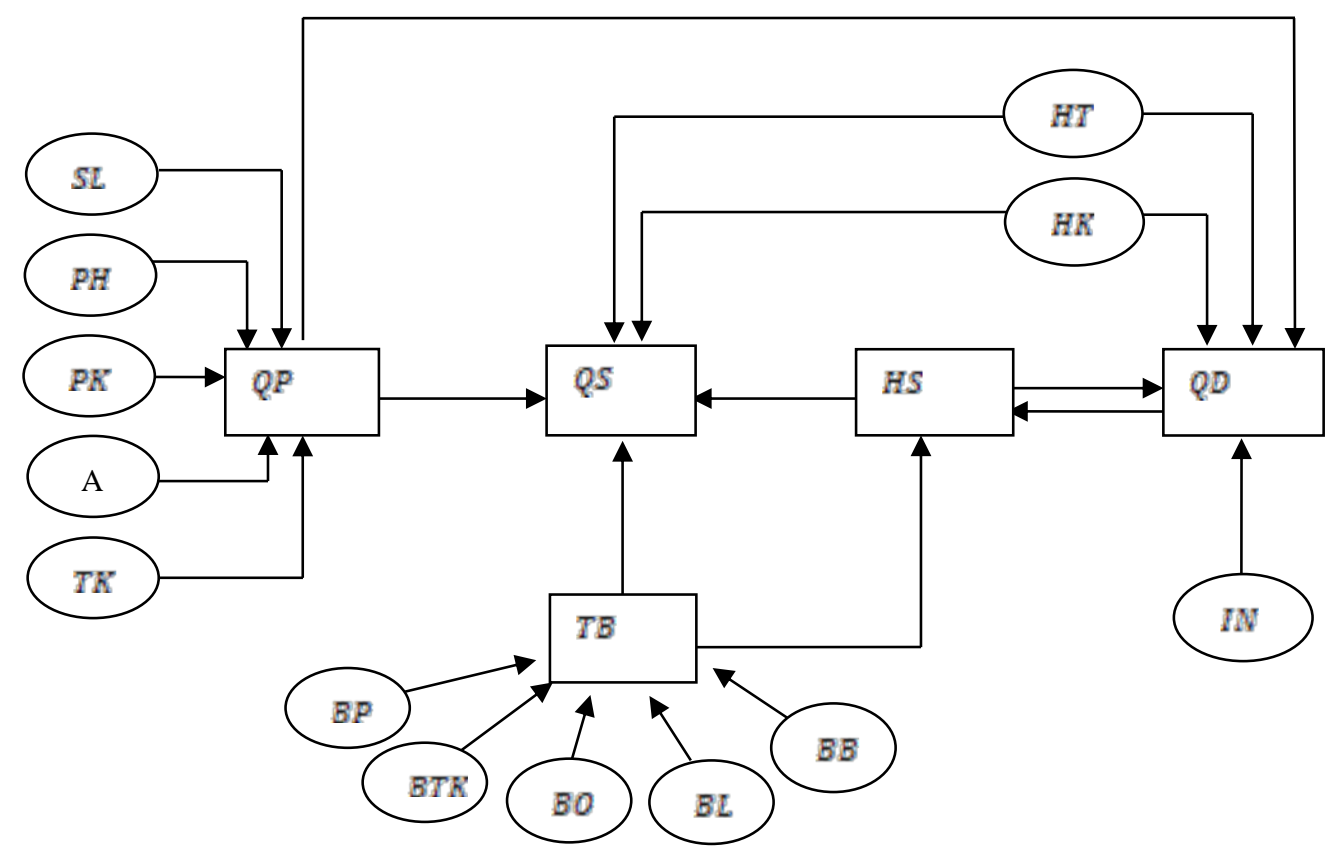

Gambar 1. Dugaan Keterkaitan Hubungan antar Variabel dalam Model

$$
\text { Keterangan }: \square=\text { Variabel Endogen } \bigcirc=\text { Variabel Eksogen }
$$

Simbol 5 variabel endogen : QP=Jumlah produksi susu segar, $\mathrm{QS}=$ jumlah Penawaran Susu Segar, HS= Harga Susu Segar Dalam Negeri, QD = Jumlah Permintaan Susu Segar, TB= Total biaya produksi

Simbol 13 variabel eksogen : SL=Jumlah Sapi Laktasi, PH= Jumlah Pakan Hijauan, PK= Jumlah Pakan Konsentrat, TK= Jumlah Tenaga Kerja/Peternak, A= Jumlah Pemakaian Air, HT= Harga Teh, HK= Harga Kopi, BP= Biaya Pakan, BTK= Biaya Tenaga Kerja, BO= Biaya Obat-obatan, BLA= Biaya Listrik dan Air, BB= Biaya Bahan Bakar, IN= Pendapatan Per Kapita.

Berdasarkan variabel endogen pada Gambar 1 di atas, maka terdapat lima model persamaan struktural dan satu model persamaan identitas sebagai berikut :

\section{Model Persamaan Total Biaya Produksi}

$$
\begin{gathered}
T B=\alpha_{0}+\alpha_{1} B P+\alpha_{2} B T K+\alpha_{3} B L A+ \\
\alpha_{4} B O+\alpha_{5} B B+\mu_{1} \ldots \ldots(1)
\end{gathered}
$$

Estimasi parameter yang diharapkan adalah $\alpha_{1}, \alpha_{2}, \alpha_{3}, \alpha_{4}, \alpha_{5}>0$.

\section{Model Persamaan Produksi Susu Segar Dalam Negeri}

$$
\begin{aligned}
Q P= & \beta_{0}+\beta_{1} S L+\beta_{2} P H+\beta_{3} P K+\beta_{4} A+ \\
& \beta_{5} T K+\mu_{2} \ldots \ldots \ldots . .(2)
\end{aligned}
$$

Estimasi parameter yang diharapkan adalah $\beta_{1}, \beta_{2}, \beta_{3} \beta_{4}, \beta_{5}>0$.

\section{Model Persamaan Penawaran Susu Segar Dalam Negeri}

$Q S=\gamma_{0}+\gamma_{1} H S+\gamma_{2} H T+\gamma_{3} H K+\gamma_{4} Q P+$ $\gamma_{5} T B+\mu_{3}$

Estimasi parameter yang diharapkan adalah 
$\gamma_{1}, \gamma_{2}, \gamma_{3}, \gamma_{4}>0$ dan $\gamma_{5}<0$

\section{Model Persamaan Keseimbangan Pasar (Equlibrium)}

$Q S=Q D$

\section{Model Persamaan Harga Susu Segar Dalam Negeri}

$H S=\delta_{0}+\delta_{1} T B+\delta_{2} Q D+\mu_{4}$

Estimasi parameter yang diharapkan adalah $\delta_{1},>0$ dan $\delta_{2}<0$.

\section{Model Permintaan Susu Segar}

$Q D=\varepsilon_{0}+\varepsilon_{1} H S+\varepsilon_{2} H T+\varepsilon_{3} H K+\varepsilon_{4} Q P+$ $\varepsilon_{5} I N+\mu_{5}$

Estimasi parameter yang diharapkan adalah $\varepsilon_{1}<0$, dan $\varepsilon_{2}, \varepsilon_{3} \varepsilon_{4}, \varepsilon_{5}>0$.

Identifikasi model adalah syarat yang diperlukan untuk mengestimasi parameter pada setiap persamaan struktural dalam sistem persamaan simultan. Identifikasi model persaman dapat dilakukan dengan mengidentifikasi kondisi orde (order condition) dengan rumus sebagai berikut :

Dimana :

$$
K-k \geq m-1
$$

$K=$ jumlah variabel yang sudah ditetapkan (predetermined) dalam model termasuk intercept.

$K=$ jumlah variabel yang ditetapkan dalam persamaan yang diberikan.

$m$ = jumlah variabel endogen dalam persamaan yang diberikan.

Prinsip dalam menentukan identifikasi dalam model persamaan simultan, secara sederhana adalah sebagai berikut :

a. Jika $K-k \geq m-1$, persamaan tersebut adalah overidentified.

b. Jika $K-k=m-1$, persamaan tersebut adalah teridentifikasi secara tepat.

c. Jika $K-k<m-1$, persamaan struktural tidak teridentifikasi.

Hasil identifikasi model persamaan dalam penelitian ini dapat diihat secara rinci pada Tabel 1.

Tabel 1. Identifikasi Persamaan Struktural Dalam Keseimbangan Harga Susu

\begin{tabular}{cccccccc}
\hline $\begin{array}{c}\text { Model } \\
\text { Persamaan }\end{array}$ & $\boldsymbol{K}$ & $\boldsymbol{k}$ & $\boldsymbol{M}$ & $\boldsymbol{K}-\boldsymbol{k}$ & $\boldsymbol{m - 1}$ & Hasil Identifikasi & Keterangan \\
\hline TB & 18 & 5 & 1 & 13 & 0 & $13>0$ & Overidentified \\
QP & 18 & 5 & 1 & 13 & 0 & $13>0$ & Overidentified \\
QS & 18 & 5 & 3 & 13 & 2 & $13>2$ & Overidentified \\
HS & 18 & 2 & 3 & 16 & 2 & $16>2$ & Overidentified \\
QD & 18 & 5 & 3 & 13 & 2 & $13>2$ & Overidentified \\
\hline
\end{tabular}

Pengujian model yang dilakukan dalam penelitian adalah dengan uji autokorelasi, uji nilai $\mathrm{F}$, uji nilai t dan uji validasi model.

\section{HASIL DAN PEMBAHASAN \\ Deskripsi Variabel Penelitian}

Model harga keseimbangan pasar susu segar dibangun dari 5 model persamaan struktural mengacu kepada teori ekonominya, dengan jumlah variabel eksogen sebanyak 13. Lembaga penyedia data statistik adalah Badan Pusat Statistik dengan berbagai referensi yang tersedia. Kurun waktu data selama 25 tahun dari tahun 1993 sampai 2017. Data tahun 2017 merupakan data maksimum pada beberapa variabel yakni : variabel jumlah produksi susu, jumlah sapi laktasi, pakan hijauan, jumlah penawaran / permintaan susu segar, total biaya produksi dan pendapatan perkapita. Sebaran masingmasing variabel berdasarkan analisis deskripsi dapat dilihat pada Tabel 2.

Bila dilihat dari laju pertumbuhan rata-rata pertahun, jumlah produksi susu segar bertumbuh positif sebanyak 10,3\%. Jumlah 
ini masih lebih tinggi bila dibandingkan dengan laju pertumbuhan jumlah permintaan susu segar yakni 9,85\%. Yang perlu mendapat perhatian adalah laju pertumbuhan tenaga kerja yang menyusut sebesar 1,66\% dan kebutuhan obat-obatan dengan laju pertumbuhan sangat besar mencapai 185,4 $\%$. Bila dilihat perkembangan tahunan, ada pengeluaran untuk biaya obat-obatan sangat besar secara periodik lima tahunan, mungkin ini akibat serangan penyakit yang muncul secara periodik. Di sisi lain, laju pertumbuhan pendapatan perkapita masyarakat Indonesia mencapai $16,38 \%$, dapat menjadi peluang penyerapan produksi susu segar masih tersedia cukup besar.
Tiga variabel harga yakni harga susu segar dan dua harga komoditas lainnya sebagai komplemen/substitusi yaitu harga teh dan kopi, ternyata memiliki laju pertumbuhan yang relatif sama yakni $11,2-12,12$. Ini menunjukkan perubahan harga tiga komoditas tersebut selama 25 tahun relatif stabil.

Laju pertumbuhan biaya usaha sapi perah cukup tinggi mencapai $21 \%$. Biaya ini dialokasikan untuk biaya pakan ternak yang mendominasi pengeluaran sebesar 59\%, pengeluaran berikutnya tenaga kerja $16 \%$, obat-obatan $9 \%$, BBM $3 \%$ dan keperluan lain sisanya.

Tabel 2. Sebaran Deskriptif Masing-Masing Variabel Sistem Keseimbangan Harga Susu Segar

\begin{tabular}{|c|c|c|c|c|c|c|c|}
\hline Variabel & Satuan & Mean & Min & Max & Sd & LP $(\%)$ & Tahun 2017 \\
\hline QP & (Liter) & 42292048.4 & 16240950 & 126584000 & 22330519.87 & 10.3 & $126,584,000$ \\
\hline SL & (Ekor) & 12031.32 & 4229 & 37610 & 6211.22 & 11.57 & 37,610 \\
\hline $\mathrm{PH}$ & $(\mathrm{Kg})$ & 125606968 & 35637450 & 590373869.2 & 116032703.4 & 33.58 & $590,373,869$ \\
\hline $\mathrm{PK}$ & $(\mathrm{Kg})$ & 22832760.1 & 6933360 & 78347251.54 & 18459859.96 & 19.88 & $43,712,400$ \\
\hline A & (M3) & 507105.97 & 50616 & 2476122 & 633977.46 & 20.16 & 937,414 \\
\hline $\mathrm{TK}$ & (Orang) & 2519.04 & 1316 & 4234 & 948.57 & -1.66 & 1,318 \\
\hline QS & (Liter) & 41749738.9 & 15163335 & 124036117.9 & 21877680.42 & 9.85 & $124,036,118$ \\
\hline HS & (Rp/Liter) & 2691.09 & 655.86 & 7941.0 & 1807.69 & 12.12 & 5,509 \\
\hline HT & $(\mathrm{Rp} / \mathrm{Kg})$ & 38774.25 & 6154.21 & 75000 & 23011.37 & 12 & 75,000 \\
\hline $\mathrm{HK}$ & $(\mathrm{Rp} / \mathrm{Kg})$ & 24281.67 & 4348.65 & 39210 & 11843.95 & 11.2 & 38,330 \\
\hline $\mathrm{TB}$ & $(\mathrm{Rp})$ & $1.0359 \mathrm{E}+11$ & 19267594000 & $4.02218 \mathrm{E}+11$ & $1.02284 \mathrm{E}+11$ & 21 & $402,218,460,000$ \\
\hline $\mathrm{BP}$ & (Rp) & $6.0903 \mathrm{E}+10$ & 11155960000 & $2.54542 \mathrm{E}+11$ & 61646716314 & 19.7 & $254,541,890,000$ \\
\hline BTK & $(\mathrm{Rp})$ & $1.653 \mathrm{E}+10$ & 4856413000 & 51621870000 & 12699514274 & 17 & $51,621,870,000$ \\
\hline BLA & (Rp) & 2794533480 & 350200000 & 15224400000 & 3955272521 & 21.4 & $15,224,400,000$ \\
\hline $\mathrm{BO}$ & $(\mathrm{Rp})$ & 9641746320 & 585258000 & 95811920000 & 18917289345 & 185.4 & $19,962,520,000$ \\
\hline $\mathrm{BB}$ & $(\mathrm{Rp})$ & 3655844160 & 577320000 & 20438650000 & 4954288609 & 24.7 & $14,803,380,000$ \\
\hline QD & (Liter) & 41749738.9 & 15163335 & 124036117.9 & 21877680.42 & 9.85 & $124,036,118$ \\
\hline IN & (Rupiah) & 15198729.6 & 1334821.3 & 38375500 & 12097460.93 & 16.38 & $38,375,500.00$ \\
\hline
\end{tabular}

\section{Uji Validasi Model}

Data yang telah dikumpulkan perlu divalidasi sebelum di analisis menggunakan simulasi dengan metode Two Stages Least Squares (@SLS). Uji validasi data menggunakan nilai U-Theil dan nilai hasil uji autokorelasi.
Tujuan pengujian nilai U-Theil untuk memastikan bahwa model persamaan yang sudah dibangun dapat dikatakan valid, sedangkan uji autokorelasi digunakan untuk memastikan bahwa tidak ada korelasi antara kesalahan pengganggu pada periode $t$ dengan 
kesalahan pengganggu pada periode sebelumnya. Hasil pengujian tercantum pada Tabel 3 dan Tabel 4.

Tabel 3. Hasil Pengujian Model Menggunakan Uji Validasi dengan Niai U-Theil.

\begin{tabular}{|c|c|c|c|c|c|c|c|c|c|c|}
\hline & & & & Thei] & recas & Error & istics & & & \\
\hline & & & & MSE De & posit & Propc & ons & & & \\
\hline Variable & $\mathrm{N}$ & MSE & $\begin{array}{r}\text { Corr } \\
(\mathrm{R})\end{array}$ & $\begin{array}{l}\text { Bias } \\
\text { (UM) }\end{array}$ & $\begin{array}{l}\text { Reg } \\
\text { (UR) }\end{array}$ & $\begin{array}{l}\text { Dist } \\
\text { (UD) }\end{array}$ & $\begin{array}{l}\text { Var } \\
\text { (US) }\end{array}$ & $\begin{array}{r}\text { Covar } \\
\text { (UC) }\end{array}$ & $\begin{array}{l}\text { Inequality } \\
\text { U1 }\end{array}$ & $\begin{array}{c}\text { Coef } \\
\text { U }\end{array}$ \\
\hline TB & 25 & $6.062 \mathrm{E} 18$ & 1.00 & 0.00 & 0.00 & 1.00 & 0.00 & 1.00 & 0.0171 & 0.0085 \\
\hline QP & 25 & $6.727 \mathrm{E} 13$ & 0.93 & 0.00 & 0.00 & 1.00 & 0.04 & 0.96 & 0.1723 & 0.0868 \\
\hline QS & 25 & $6.938 \mathrm{E} 13$ & 0.92 & 0.01 & 0.01 & 0.99 & 0.01 & 0.98 & 0.1775 & 0.0886 \\
\hline QD & 25 & $4.183 \mathrm{E} 13$ & 0.95 & 0.00 & 0.00 & 1.00 & 0.02 & 0.98 & 0.1378 & 0.0692 \\
\hline HS & 25 & 180018 & 0.97 & 0.02 & 0.00 & 0.98 & 0.00 & 0.98 & 0.1317 & 0.0655 \\
\hline
\end{tabular}

Uji Autokorelasi menggunakan metode uji Durbin-Watson, hasil pengujian tercantum pada Tabel 4 berikut :

Tabel 4. Hasil Pengujian Model dengan Uji Autokorelasi Durbin Watson

\begin{tabular}{|c|c|c|c|}
\hline Model Persamaan & $\begin{array}{l}\text { Nilai Durbin } \\
\text { Watson }\end{array}$ & Pengambilan Keputusan & Hasil \\
\hline $\begin{array}{lll}\text { Total biaya } & \text { produksi } \\
\text { (TB) } & & \end{array}$ & 2,392 & $\begin{array}{c}\mathrm{d}_{\mathrm{U}}<\mathrm{d}<4-\mathrm{d}_{\mathrm{U}} \\
(1,886<2,392<2,114)\end{array}$ & $\begin{array}{c}\text { Tidak Terdapat } \\
\text { Autokorelasi }\end{array}$ \\
\hline $\begin{array}{lll}\begin{array}{l}\text { Produksi } \\
\text { (QP) }\end{array} & \text { Susu Segar } \\
\end{array}$ & 1,744 & $\begin{array}{c}\mathrm{d}_{\mathrm{L}} \leq \mathrm{d} \leq \mathrm{d}_{\mathrm{U}} \\
(0,953<1,744<1,886)\end{array}$ & Tidak Ada Keputusan \\
\hline $\begin{array}{l}\text { Penawaran Susu Segar } \\
\text { (QS) }\end{array}$ & 1,958 & $\begin{array}{c}\mathrm{d}_{\mathrm{U}}<\mathrm{d}<4-\mathrm{d}_{\mathrm{U}} \\
(1,886<1,958<2,114)\end{array}$ & $\begin{array}{l}\text { Tidak Terdapat } \\
\text { Autokorelasi }\end{array}$ \\
\hline $\begin{array}{l}\text { Permintaan Susu Segar } \\
\text { (QD) }\end{array}$ & 1,461 & $\begin{array}{c}\mathrm{d}_{\mathrm{L}} \leq \mathrm{d} \leq \mathrm{d}_{\mathrm{U}} \\
(0,953<1,461<1,886)\end{array}$ & Tidak Ada Keputusan \\
\hline Harga Susu Segar (HS) & 2,111 & $\begin{array}{c}\mathrm{d}_{\mathrm{U}}<\mathrm{d}<4-\mathrm{d}_{\mathrm{U}} \\
(1,550<2,111<2,450)\end{array}$ & $\begin{array}{c}\text { Tidak Terdapat } \\
\text { Autokorelasi }\end{array}$ \\
\hline
\end{tabular}

Mengacu kepada pernyataan Sunyoto (2010) apabila nilai durbin watson berada diantara nilai -2 dan 2, maka dapat disimpulkan bahwa model persamaan tidak mengalami masalah autokorelasi.

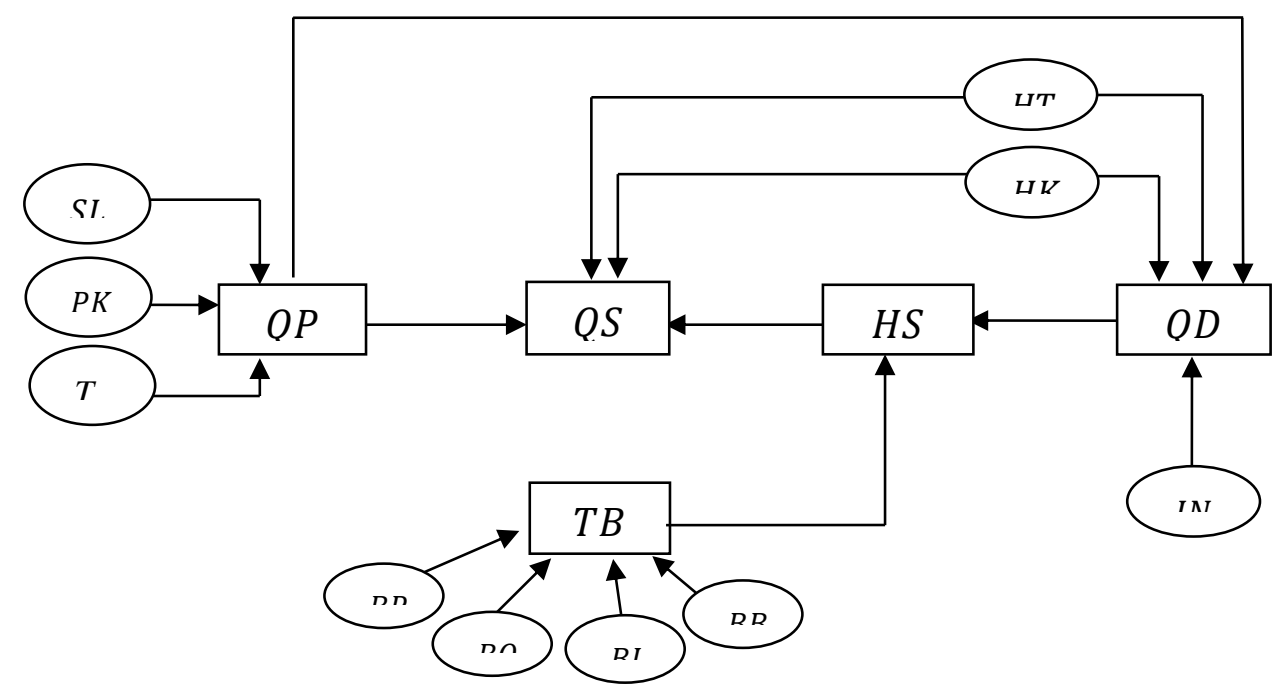

Gambar 2. Keterkaitan Hubungan antar Variabel dalam Model persamaan yang telah divalidasi 
Dari hasil pengujian validasi dan autokorelasi maka lima model persamaan telah memenuhi syarat validasi sehingga dapat dibangun skema sistem keseimbangan harga pasar susu sapi segar domestik di Indonesia sebagaimana tercantum pada Gambar 2. Hubungan antara model persamaan satu dengan lainnya dapat diidentifikasi menggunakan analisis simulasi dengan metode Two Stages Least Squares (@SLS). Sistem keseimbangan harga pasar susu segar dibangun dari lima model persamaan yaitu :

1. Model total biaya produksi dipengaruhi oleh biaya pakan, biaya listrik dan air, biaya obat-obatan serta biaya bahan bakar yang berpengaruh signifikan pada taraf nyata $\alpha$ sebesar 0,05 .

2. Model produksi susu segar di Indonesia dipengaruhi oleh jumlah sapi laktasi dan jumlah pakan konsentrat pada taraf nyata $\alpha$ sebesar 0,05 .

3. Model penawaran susu segar dipengaruhi oleh jumlah produksi susu segar, harga teh dan harga kopi yang berpengaruh secara signifikan terhadap jumlah penawaran pada taraf nyata $\alpha$ sebesar 0,05 .
4. Model permintaan susu segar dipengaruhi oleh variabel harga teh, harga kopi, jumlah produksi susu segar dan jumlah pendapatan perkapita pada taraf nyata $\alpha$ sebesar 0,05.

5. Model harga susu segar dipengaruhi oleh total biaya dan jumlah permintaan pada taraf nyata $\alpha$ sebesar 0,05 .

\section{Faktor-Faktor yang Mempengaruhi Total Biaya produksi}

Model persamaan total biaya produksi susu segar memiliki nilai koefisien determinasi $\left(\mathrm{R}^{2}\right)$ sebesar 0,99 yang menunjukkan bahwa sebesar 99\% keragaman nilai total biaya produksi susu segar dapat dijelaskan oleh keragaman variabel biaya pakan, biaya tenaga kerja, biaya listrik dan air, biaya obat-oabtan dan biaya bahan bakar. Dari hasil uji statistik F memiliki nilai probabilitas sebesar $<0,0001$, maka dapat disimpulkan bahwa variabel-variabel penjelas secara serentak berpengaruh nyata $(\alpha=0,05)$ terhadap model persamaan total biaya produksi susu segar. Adapun hasil uji statistik t dapat dilihat pada Tabel 5.

Tabel 5. Hasil Uji statistik t Model Persamaan Total Biaya Produksi Susu Segar

\begin{tabular}{|c|c|c|c|c|c|c|}
\hline \multicolumn{7}{|c|}{ Parameter Estimates } \\
\hline Variable & DF & $\begin{array}{l}\text { Parameter } \\
\text { Estimate }\end{array}$ & $\begin{array}{r}\text { Standard } \\
\text { Error }\end{array}$ & t Value & $\operatorname{Pr}>|t|$ & $\begin{array}{l}\text { Variable } \\
\text { Label }\end{array}$ \\
\hline Intercept & 1 & $3.83 \mathrm{E} 9$ & $1.9721 \mathrm{E} 9$ & 1.94 & 0.0671 & Intercept \\
\hline $\mathrm{BP}$ & 1 & 0.975953 & 0.101973 & 9.57 & $<.0001$ & Biaya Pakan \\
\hline BTK & 1 & 0.558895 & 0.425283 & 1.31 & 0.2044 & Biaya Tenaga Kerja \\
\hline BLA & 1 & 5.226691 & 0.800654 & 6.53 & $<.0001$ & Biaya Listrik dan Air \\
\hline BO & 1 & 1.112180 & 0.104897 & 10.60 & $<.0001$ & Biaya Obat-obatan \\
\hline BB & 1 & 1.574524 & 0.258978 & 6.08 & $<.0001$ & Biaya Bahan Bakar \\
\hline
\end{tabular}

Berdasarkan nilai uji statistik $\mathrm{t}$ diperoleh hasil bahwa biaya pakan, biaya listrik dan air, biaya obat-obatan dan biaya bahan bakar berpengaruh secara signifikan pada taraf nyata $\alpha$ sebesar 0,05 . Sedangkan variabel biaya tenaga kerja tidak berpengaruh secara signifikan terhadap nilai total biaya produksi.

Nilai dugaan parameter semua variabel memiliki tanda positif yang menunjukkan adanya hubungan searah antara semua variabel (pakan, tenaga kerja, listrik/air, obatobatan dan bahan bakar) dengan nilai total total biaya produksi. Tanda positif sesuai dengan hipotesis masing-masing variabel pada model persamaan total biaya usaha sapi perah.

Dugaan parameter pada variabel biaya pakan dengan angka sebesar 0,97 , berarti apabila 
terjadi kenaikan satu rupiah biaya pakan maka total biaya produksi susu segar yang dikeluarkan akan meningkat sebesar 0,97 rupiah dengan faktor lain dianggap tetap (ceteris paribus). Hal ini sesuai dengan penjelasan Ako (2013) bahwa biaya pakan memiliki pengaruh yang signifikan karena pakan merupakan salah satu faktor produksi yang sangat penting dalam pemeliharaan ternak sapi perah dan memiliki persentase biaya pakan mencapai $60-70 \%$ dari total biaya.

Selanjutnya dugaan parameter biaya listrik dan air memiliki nilai positif dengan angka sebesar 5,22. Ini menunjukkan bahwa apabila terjadi kenaikan satu rupiah biaya listrik dan air maka total biaya produksi susu segar yang dikeluarkan akan meningkat sebesar 5,22 rupiah dengan faktor lain dianggap tetap (ceteris paribus). Adapun dugaan parameter biaya obat-obatan dan vaksin memiliki nilai positif dengan angka sebesar 1,11. Ini menunjukkan bahwa apabila terjadi kenaikan satu rupiah biaya obat-obatan maka total biaya produksi susu segar yang dikeluarkan akan meningkat sebesar 1,11 rupiah dengan faktor lain dianggap tetap (ceteris paribus). Terakhir dugaan parameter bahan bakar memiliki nilai positif dengan angka sebesar
1,57. Ini menunjukkan bahwa apabila terjadi kenaikan satu rupiah biaya bahan bakar maka total biaya produksi susu segar yang dikeluarkan akan meningkat sebesar 1,57 rupiah dengan faktor lain dianggap tetap (ceteris paribus).

\section{Faktor-Faktor yang Mempengaruhi Produksi Susu Segar}

Model persamaan produksi susu segar memiliki nilai koefisien determinasi $\left(\mathrm{R}^{2}\right)$ sebesar 0,863. Berdasarkan nilai koefisien determinasi tersebut dapat diartikan bahwa sebesar 86,3\% keragaman produksi susu segar dapat dijelaskan oleh keragaman variabel jumlah sapi perah laktasi, jumlah pakan hijauan, jumlah pakan konsentrat, jumlah pemakaian air dan jumlah tenaga kerja. Hasil uji statistik $\mathrm{F}$ memiliki nilai probabilitas sebesar <0,0001 maka dapat disimpulkan bahwa variabel-variabel penjelas secara serentak berpengaruh nyata terhadap model persamaan produksi susu segar. Hasil uji statistik $\mathrm{t}$ dalam pengolahan data dengan perangkat lunak SAS 9.1 dapat dilihat pada Tabel 6 berikut :

Tabel 6. Hasil Uji statistik t Model Jumlah Produksi Susu Segar

\begin{tabular}{|c|c|c|c|c|c|c|}
\hline \multicolumn{7}{|c|}{ Parameter Estimates } \\
\hline Variable & DF & $\begin{array}{c}\text { Parameter } \\
\text { Estimate }\end{array}$ & $\begin{array}{r}\text { Standard } \\
\text { Error }\end{array}$ & t Value & $\operatorname{Pr}>|t|$ & $\begin{array}{l}\text { Variable } \\
\text { Label }\end{array}$ \\
\hline Intercept & 1 & 16624231 & 9671670 & 1.72 & 0.1019 & Intercept \\
\hline SL & 1 & 2013.709 & 567.9169 & 3.55 & 0.0022 & Jumlah Sapi Laktasi \\
\hline $\mathrm{PH}$ & 1 & 0.033757 & 0.026696 & 1.26 & 0.2213 & Jumlah Pakan Hijauan \\
\hline PK & 1 & 0.306111 & 0.135832 & 2.25 & 0.0362 & Jumlah Pakan Konsentrat \\
\hline$A$ & 1 & 4.276724 & 4.412099 & 0.97 & 0.3446 & Jumlah pemakaian air \\
\hline TK & 1 & -4747.05 & 3088.200 & -1.54 & 0.1407 & Jumlah Tenaga kerja \\
\hline
\end{tabular}

Dugaan parameter semua variabel pada model persamaan produksi susu segar bertanda positif kecuali pada variabel tenaga kerja yang menunjukkan arah negatif terhadap jumlah produksi susu segar. Sapi laktasi merupakan sapi perah betina yang sedang berproduksi menghasilkan susu. Berdasarkan hasil uji $t$, diperoleh nilai probabilitas jumlah sapi laktasi sebesar 0,0022 lebih kecil dari $\alpha$ sebesar 0,05 yang menunjukkan pengaruh signifikan terhadap jumlah produksi susu segar. Besarnya dugaan parameter sapi laktasi 2013,7 yang menunjukkan makna apabila terjadi penambahan satu ekor jumlah sapi laktasi, maka jumlah produksi susu segar yang 
dihasilkan akan meningkat sebesar 2.013,7 liter per tahun dengan faktor lain dianggap tetap (ceteris paribus). Hal tersebut sesuai dengan Siregar (2003) yang menyatakan bahwa penambahan populasi sapi perah betina merupakan salah satu alternatif dalam meningkatkan produksi susu nasional.

Besaran dugaan parameter jumlah pakan konsentrat 0,306 dengan arah postif dan signifikansi pada taraf nyata $\alpha$ sebesar 0,05 . Maknanya, apabila terjadi penambahan pemberian jumlah pakan konsentrat sebesar 1 $\mathrm{kg}$, maka jumlah produksi susu segar akan meningkat sebesar 0,3 liter dengan asumsi faktor lain dianggap tetap (ceteris paribus). Hasil penelitian Siregar (2001) membuktikan suplementasi pakan konsentrat yang lebih tinggi kandungan protein dan energinya sebanyak 2,0-2,5 $\mathrm{kg} / \mathrm{ekor} / \mathrm{hari}$ dengan frekuensi pemberian pakan 3 kali sehari, dapat meningkatkan kemampuan berproduksi susu sekitar 22,05-23,62\%.

\section{Faktor-Faktor yang Mempengaruhi Penawaran Susu Segar}

Berdasarkan hasil uji determinan model penawaran susu segar, diperoleh nilai $\mathrm{R}^{2}$ sebesar 0,95. Nilai tersebut memiliki arti bahwa keragaman variabel penawaran susu segar dapat dijelaskan oleh keragaman variabel jumlah produksi susu segar, nilai total biaya produksi dan harga susu segar sebesar 95\%. Dan nilai uji statistik $\mathrm{F}$, diperoleh nilai probabilitas sebesar $<0,0001$. Apabila dibandingkan dengan nilai taraf nyata $\alpha$ sebesar 0,05 maka dapat disimpulkan bahwa variabel-variabel eksogen berpengaruh signifikan terhadap variabel endogen secara serentak. Adapun hasil uji estimasi parameter dari model penawaran susu segar dengan perangkat lunak SAS 9.1.dapat dilihat pada Tabel 7.

Tabel 7. Hasil Uji Statistik t Model Jumlah Penawaran Susu Segar.

\begin{tabular}{|lcccccl|}
\hline & & \multicolumn{5}{c|}{ Parameter Estimates } \\
Variable & DF & $\begin{array}{c}\text { Parameter } \\
\text { Estimate }\end{array}$ & $\begin{array}{c}\text { Standard } \\
\text { Error }\end{array}$ & t Value & $\mathrm{Pr}>|\mathrm{t}|$ & $\begin{array}{l}\text { Variable } \\
\text { Label }\end{array}$ \\
Intercept & 1 & $-3.965 \mathrm{E} 7$ & 31488886 & -1.26 & 0.2232 & Intercept \\
HS & 1 & 18410.21 & 11989.96 & 1.54 & 0.1412 & Harga Susu Segar \\
HT & 1 & -784.284 & 277.4193 & -2.83 & 0.0108 & Harga Teh \\
HK & 1 & 886.4216 & 443.3821 & 2.00 & 0.0601 & Harga Kopi \\
QP & 1 & 1.883196 & 0.780100 & 2.41 & 0.0260 & Jumlah Produksi Susu Segar \\
TB & 1 & -0.00038 & 0.000316 & -1.19 & 0.2490 & Total Biaya Produksi \\
\hline
\end{tabular}

Arah dugaan parameter terhadap penawaran susu segar terdapat dua jenis yaitu harga susu segar, harga kopi dan jumlah produksi susu segar bertanda postif, variabel lainnya yaitu harga teh dan total biaya produksi memiliki arah negatif terhadap penawaran susu segar. Variabel harga susu segar memiliki nilai probabilitas uji statistik $\mathrm{t}$ sebesar 0,14 lebih kecil dari taraf nyata $(\alpha)$ sebesar 0,15 sehingga berpengaruh nyata pada taraf ( $\alpha=$ 0,15). Variabel harga teh dan jumlah produksi memiliki nilai signifikansi pada taraf nyata $(\alpha=0,1)$. Dan variabel harga kopi berpengaruh signifikan pada taraf nyata ( $\alpha=$ $0,05)$
Dugaan parameter variabel harga susu segar memiliki tanda positif dengan nilai 18.410. Artinya, bahwa apabila terjadi kenaikan harga susu segar sebesar 1 Rupiah, maka jumlah penawaran susu segar akan bertambah sebanyak 18.410 liter per tahun dengan faktor lain dianggap tetap (ceteris paribus). Hal ini sejalan dengan teori yang dikemukakan oleh Rahardja dan Manurung (2010) yang menyatakan bahwa harga suatu barang memiliki hubungan positif terhadap jumlah penawaran. Artinya apabila terjadi kenaikan harga sebesar 1 satuan, maka produsen akan meningkatkan jumlah penawaran sebanyak 1 satuan. 
Saat ini peternak sapi perah menjual susu segar dengan harga sekitar Rp. 3,800 sampai dengan Rp. 5,300 per liter. Sedangkan, menurut perhitungan Asosiasi Peternak Sapi Perah Indonesia (APSPI) dalam Sidik (2018) bahwa harga susu segar yang layak ditingkat peternak berkisar pada harga Rp. 7,500 sampai Rp. 7,800 per liter. Dengan harga tersebut diyakini peternak dapat konsisten memproduksi susu berkualitas dengan jumlah yang memenuhi kebutuhan industry.

Dugaan parameter harga teh sebesar 784,28 dan tanda arah negatif, yang maknanya apabila terjadi kenaikan harga teh sebesar 1 Rupiah, maka jumlah penawaran susu segar akan berkurang sebanyak 784,28 liter per tahun dengan faktor lain dianggap tetap (ceteris paribus). Mengacu kepada teori Rahardja dan Manurung (2010) bahwa apabila harga suatu barang substusi meningkat, maka penawaran suatu barang juga akan meningkat (bersifat searah). Sebaliknya apabila harga barang komplementer meningkat, maka penawaran suatu barang akan menurun (bersifat tidak searah). Dapat disimpulkan bahwa komoditas teh merupakan barang komplementer bagi komoditas susu segar. Kesimpulan yang sama juga ditunjukkan oleh hasil perhitungan elastisitas silang antara harga teh terhadap penawaran susu segar. Berdasarkan hasil perhitungan elastisitas silang menghasilkan nilai sebesar - 0,73. Menurut Syamsuddin dan Karya (2018), tanda negatif pada nilai elastisitas silang menunjukkan bahwa kedua komoditas memiliki hubungan komplementer.

Hal sebaliknya terjadi pada harga kopi, nilai probabilitas uji statistik t sebesar 0,06 dengan tanda positif. Nilai tersebut menunjukkan bahwa nilai probabilitas lebih kecil jika dibandingkan dengan nilai taraf nyata $(\alpha)$ sebesar 0,10. Dugaan parameter harga kopi sebesar 886,4 yang memberikan makna apabila terjadi kenaikan harga kopi sebesar 1 Rupiah, maka jumlah penawaran susu segar akan bertambah sebanyak 886 liter per tahun dengan faktor lain dianggap tetap (ceteris paribus). Tanda positif arah variabel harga kopi terhadap penawaran susu segar memposisikan harga kopi sebagai substitusi bagi harga susu segar. Diperkuat dengan hasil perhitungan nilai elastisitas silang harga kopi bernilai positif 0,51 yang menunjukkan kedua komoditas harga kopi dan harga susu segar sebagai substitusi.

Variabel produksi susu segar memiliki nilai probabilitas uji statistik t sebesar 0,026. Nilai tersebut menujukkan bahwa nilai probabilitas lebih kecil jika dibandingkan dengan nilai taraf nyata $(\alpha)$ sebesar 0,05 . Sehingga dapat diambil kesimpulan bahwa banyaknya jumlah produksi susu segar berpengaruh signifikan terhadap banyaknya jumlah susu yang akan ditawarkan. Adapun dugaan parameter variabel jumlah produksi susu segar memiliki pengaruh positif dengan nilai sebesar 1,88. Tanda positif bermakna bahwa jumlah produksi memiliki hubungan searah dengan jumlah penawaran. Artinya, apabila terjadi peningkatan jumlah produksi sebesar 1 liter, maka jumlah penawaran susu segar akan meningkat sebesar 1,88 liter.

\section{Faktor-Faktor yang Mempengaruhi Permintaan Susu Segar}

Berdasarkan uji determinan model permintaan susu segar, diperoleh nilai $\mathrm{R}^{2}$ sebesar 0,97 . Nilai tersebut memiliki arti bahwa keragaman variabel permintaan susu segar dapat dijelaskan oleh keragaman variabel eksogen sebesar 97\%. Sedangkan hasil uji statistik F dengan nilai probabilitas sebesar $<0,0001$ menunjukkan bahwa variabel-variabel eksogen berpengaruh signifikan terhadap variabel endogen secara serentak pada taraf nyata $\alpha$ sebesar 0,05 . Berdasarkan uji statistik $\mathrm{t}$ diperoleh hasil bahwa harga teh, harga kopi, jumlah produksi susu segar dan jumlah pendapatan perkapita berpengaruh signifikan terhadap jumlah permintaan susu segar pada taraf nyata $\alpha$ sebesar 0,05 . Secara rinci hasil uji statistik t dicantumkan pada Tabel 8. 
Tabel 8. Hasil Uji Statistik t Model Permintaan Susu Segar

\begin{tabular}{|c|c|c|c|c|c|c|}
\hline \multicolumn{7}{|c|}{ Parameter Estimates } \\
\hline Variable & DF & $\begin{array}{c}\text { Parameter } \\
\text { Estimate }\end{array}$ & $\begin{array}{r}\text { Standard } \\
\text { Error }\end{array}$ & t Value & $\operatorname{Pr}>|t|$ & $\begin{array}{l}\text { Variable } \\
\text { Label }\end{array}$ \\
\hline Intercept & 1 & 2457141 & 3031220 & 0.81 & 0.4276 & Intercept \\
\hline HS & 1 & 2041.087 & 1430.301 & 1.43 & 0.1698 & Harga Susu Segar \\
\hline HT & 1 & -1212.60 & 262.8975 & -4.61 & 0.0002 & Harga Teh \\
\hline HK & 1 & 1125.307 & 348.7785 & 3.23 & 0.0044 & Harga Kopi \\
\hline QP & 1 & 0.881097 & 0.052983 & 16.63 & $<.0001$ & Jumlah Produksi susu segar \\
\hline IN & 1 & 1.067846 & 0.333465 & 3.20 & 0.0047 & Jumlah Pendapatan perkapita \\
\hline
\end{tabular}

Arah dugaan parameter semua variabel bertanda positif kecuali pada harga teh yang memiliki arah negatif terhadap permintaan susu segar. Variabel Harga susu segar bertanda positif dan tidak berpengaruh terhadap permintaan susu segar, hal ini sejalan dengan penelitian Zuhriyah (2010), yaitu harga susu segar memiliki tanda positif terhadap jumlah permintaan susu, yang artinya bahwa apabila terjadi kenaikan harga susu segar satu Rupiah, maka jumlah permintaan susu segar akan ikut meningkat sebanyak 1 satuan. Hal tersebut dapat terjadi karena posisi susu segar sebagai bahan baku industri masih belum sepenuhnya dapat digantikan oleh bahan baku susu impor. Permintaan susu segar sebagai bahan baku industri susu masih belum maksimal terpenuhi oleh jumlah produksi susu segar. Sehingga berapapun hasil yang diproduksi peternak maka susu segar tersebut habis terserap industri tanpa memperhatikan harga jualnya.

\section{Faktor-Faktor yang Mempengaruhi Harga Susu Segar}

Berdasarkan hasil estimasi model harga susu segar, diperoleh nilai $\mathrm{R}^{2}$ sebesar 0,97 . Nilai tersebut memiliki arti bahwa keragaman variabel harga susu segar dapat dijelaskan oleh keragaman variabel total biaya produksi, jumlah permintaan susu segar dan jumlah pendapatan perkapita sebesar $97 \%$. Hasil uji statistik $\mathrm{F}$ dengan nilai probabilitas $<0,0001$ menunjukkan bahwa nilai probabilitas $\mathrm{F}$ lebih kecil jika dibandingkan dengan taraf nyata sebesar 0,05. Sehingga, dapat disimpulkan bahwa variabel-variabel eksogen berpengaruh signifikan terhadap variabel endogen secara serentak. Berdasarkan uji statistik t diperoleh hasil bahwa total biaya produksi, dan jumlah permintaan berpengaruh signifikan terhadap jumlah harga susu segar pada taraf nyata $\alpha$ sebesar 0,05 . Sedangkan hasil pendugaan parameter dari model harga susu segar terdapat pada Tabel 9.

Tabel 9. Hasil Uji Statistik t Model Harga Susu Segar.

\begin{tabular}{|lrrrrll|}
\hline \multicolumn{7}{c|}{ Parameter Estimates } \\
Variable & DF $\begin{array}{r}\text { Parameter } \\
\text { Estimate }\end{array}$ & $\begin{array}{r}\text { Standard } \\
\text { Error }\end{array}$ t Value $\mathrm{Pr}>|\mathrm{t}|$ & $\begin{array}{l}\text { Variable } \\
\text { Label }\end{array}$ \\
Intercept & 1 & 2741.325 & 151.0998 & 18.14 & $<.0001$ & Intercept \\
TB & 1 & $2.84 \mathrm{E}-8$ & $1.166 \mathrm{E}-9$ & 24.36 & $<.0001$ & $\begin{array}{l}\text { Total Total biaya Produksi } \\
\text { Jumlah Permintaan }\end{array}$ \\
QD & 1 & -0.00007 & $5.692 \mathrm{E}-6$ & -12.59 & $<.0001$ & \\
\hline
\end{tabular}


Variabel total biaya produksi dalam penelitian memiliki nilai probabilitas uji $\mathrm{t}$ sebesar <0,0001. Apabila nilai tersebut dibandingkan dengan nilai taraf nyata $\alpha$ sebesar 0,05, maka dapat diartikan bahwa total biaya produksi berpengaruh secara signifikan terhadap harga susu segar. Nilai koefisien parameter variabel total biaya produksi memiliki hasil dengan tanda positif dengan nilai sebesar 0,0000284. Artinya, apabila terjadi peningkatan jumlah total biaya produksi sebesar 1 Rupiah, maka harga susu segar akan meningkat sebesar 0,000028 Rupiah.

Variabel jumlah permintaan susu segar dalam penelitian memiliki nilai probabilitas uji $\mathrm{t}$ sebesar <0,0001. Apabila nilai tersebut dibandingkan dengan nilai taraf nyata $\alpha$ sebesar 0,05 maka dapat diartikan bahwa jumlah permintaan susu segar berpengaruh secara signifikan terhadap harga susu segar. Nilai koefisien estimasi variabel jumlah permintaan susu segar memiliki pengaruh negatif dengan nilai sebesar -0,00007. Artinya, apabila terjadi peningkatan jumlah permintaan susu segar sebanyak 1 liter, maka harga susu segar akan menurun sebesar 0,00007 Rupiah.

\section{KESIMPULAN}

Berdasarkan pembahasan di atas maka dapat disimpulkan bahwa

1. Faktor-faktor yang berpengaruh terhadap total biaya produksi susu sapi adalah biaya pakan, biaya listrik dan air, biaya obat-obatan serta biaya bahan bakar.

2. Produksi susu segar di Indonesia dipengaruhi oleh jumlah sapi laktasi dan jumlah pakan konsentrat yang berpengaruh positif.

3. Faktor-faktor yang berpengaruh signifikan terhadap penawaran susu segar adalah jumlah produksi susu segar, harga susu segar, harga teh sebagai komoditas komplementer dan harga kopi sebagai komoditas substitusi.

4. Faktor-faktor yang berpengaruh signifikan terhadap permintaan susu segar adalah variabel harga teh sebagai komplementer, harga kopi sebagai substitusi, jumlah produksi susu segar dan jumlah pendapatan perkapita

5. Faktor-faktor yang berpengaruh signifikan terhadap harga susu segar adalah faktor total biaya dan jumlah permintaan

\section{Disarankan :}

1. Total biaya susu segar cenderung meningkat karena komponen biaya seperti pakan konsentrat, listrik/air, obat-obatan dan bahan bakar cenderung semakin tinggi harganya, diperlukan kelihaian peternak untuk mengoptimalkan penggunaan biaya produksi

2. Peningkatan jumlah produksi susu segar dalam negeri perlu dilakukan untuk memenuh jumlah permintaan yang diperkirakan bertambah seiring dengan peningkatan pendapatan perkapita

3. Upaya peningkatan produksi susu segar dalam negeri dapat dilakukan dengan penambahan input produksi sapi laktasi dengan memperhatikan pemberian jumlah pakan hijauan dan konsentrat. Jumlah sapi laktasi yang dibutuhkan sekitar 1.204.144 ekor.

4. Diperlukan adanya kepastian harga susu segar di tingkat peternak yang menarik dan memberikan keuntungan yang optimal sehingga mampu memotivasi bagi peternak untuk meningkatkan skala usaha sapi perah, selanjutnya akan mampu mendorong meningkatkan produktivitas susu sapi segar dalam negeri.

5. Peluang usaha agribisnis peternakan sapi perah masih terbuka lebar, mengingat bahwa pemenuhan kebutuhan susu segar dalam negeri masih belum terpenuhi oleh usaha peternakan yang ada.

\section{DAFTAR PUSTAKA}

Ako, Ambo. 2013. Ilmu Ternak Perah Daerah Tropis. IPB Press, Bogor.

Badan Pusat Statistik. 2018. PDB Triwulanan 
Atas Dasar Harga Konstan 2010 Menurut Lapangan Usaha ; 1. https://www.bps.go.id/dynamictable /2015/05/06/827/-seri-2010-pdbtriwulanan-atas-dasar-hargakonstan-2010-menurut-lapanganusaha-miliar-rupiah-20142018.html. Diakses pada 09 Juni 2018 pukul 21.38 WIB.

Badan Pusat Statistik. 2017. Hasil Survei Struktur Ongkos Usaha Peternakan 2017. Badan Pusat Statistik, Jakarta. (berbagai tahun )

Hasanah, Ani Nasihatul. 2015. Faktor-Faktor yang Mempengaruhi Produksi Susu Sapi Perah dan Analisis Pendapatan Peternak Studi Kasus Peternakan Kampung 99 Pepohonan [Skripsi]. Program Studi Agribisnis, Fakultas Sains dan Teknologi, UIN Syarif Hidayatullah Jakarta.

Kementerian Pertanian RI. 2018. Kemitraan Tetap Lanjut Meski ada Permentan Persusuan yang Baru ;1 http://www.pertanian.go.id/home/?s how $=$ news\&act $=$ view\&id $=3322$.

Diakses pada 14 Februari 2019 pukul 6:45 WIB.

Kusnadi, Uka dan E Juarini. 2007. Optimalisasi Pendapatan Usaha Pemeliharaan Sapi Perah dalam Upaya Peningkatan Produksi Susu Nasional [jurnal]. Wartazoa Volume 17 No 1 Th 2007. Balai Penelitian Ternak, Bogor.

Rahardja, Pratama dan Mandala Manurung. 2010. Teori Ekonomi Mikro, Suatu Pengantar, Edisi keempat. Lembaga Penerbit Fakultas Ekonomi Universitas Indonesia, Jakarta.

Sidik, Syahrizal. 2018. Belum Memadai, Harga Susu yang Layak diTingkat
Peternak Rp.7,500 - Rp. 7,800 per Liter; 1 .

http://www.tribunnews.com/bisnis/2 018/07/30/belum-memadai-hargasusu-yang-layak-di-tingkat-peternakrp-7500-rp-7800-per-liter. Diakses pada 31 Januari 2019 pukul 20:48 WIB.

Siregar, Sori B. 2003. Peluang dan Tantangan Peningkatan Produksi Susu Nasional [Jurnal]. WARTAZOA Vol. 13 No.2 Th. 2003. Balai Penelitian Ternak, Bogor.

Supianto. 2018. Kementan Target 2025 Kebutuhan Susu Nasional Terpenuhi; 1 .

http://www.jurnas.com/artikel/31201 /Kementan-Target-2025-KebutuhanSusu-Nasional-Terpenuhi/. Diakses pada 13 Februari 2019 Pukul 8:14 WIB.

Supriadi,dkk. 2017. Pengaruh Pemberian Ransum Berbagai Kualitas Pada Produksi Air Susu Peranakan Sapi Perah Friesian Holstein Di Kabupaten Sleman Yogyakarta [Jurnal]. Pengkajian dan Pengembangan Teknologi Pertanian, Vol. 20, No.1, Maret 2017: 47-58. Balai Pengkajian Teknologi Pertanian, Yogyakarta.

Syamsuddin, Syamri dan Detri Karya. 2018. Mikroekonomi untuk Manajemen. Rajawali Press, Depok.

Zuhriyah, Amanatuz. 2010. Analisis Permintaan dan Penawaran Susu Segar di Jawa Timur [Jurnal]. EMBRYO Vol.7 Desember 2010 No.2 ISSN 0216-0188. Jurusan Agribisnis, Fakultas Ilmu Pertanian Universitas Trunojoyo, Jawa Timur. 